\title{
Grammar of Difference. General Education in the Netherlands and Java, 1800-1940
}

\section{By Elise van Nederveen Meerkerk}

To cite this article: van Nederveen Meerkerk, E. (2021). Grammar of Difference. General Education in the Netherlands and Java, 1800-1940. Historical Life Course Studies, 10, 119-123. https://doi.org/10.51964/hlcs9579

\section{HISTORICAL LIFE COURSE STUDIES}

Not Like Everybody Else.

Essays in Honor of Kees Mandemakers

VOLUME 10, SPECIAL ISSUE 3

2021

GUEST EDITORS

Hilde Bras

Jan Kok

Richard L. Zijdeman 


\section{HISTORICAL LIFE COURSE STUDIES}

Historical Life Course Studies is the electronic journal of the European Historical Population Samples Network (EHPSNet). The journal is the primary publishing outlet for research involved in the conversion of existing European and nonEuropean large historical demographic databases into a common format, the Intermediate Data Structure, and for studies based on these databases. The journal publishes both methodological and substantive research articles.

\section{Methodological Articles}

This section includes methodological articles that describe all forms of data handling involving large historical databases, including extensive descriptions of new or existing databases, syntax, algorithms and extraction programs. Authors are encouraged to share their syntaxes, applications and other forms of software presented in their article, if pertinent, on the openjournals website.

\section{Research articles}

This section includes substantive articles reporting the results of comparative longitudinal studies that are demographic and historical in nature, and that are based on micro-data from large historical databases.

Historical Life Course Studies is a no-fee double-blind, peer-reviewed open-access journal supported by the European Science Foundation (ESF, http://www.esf.org), the Scientific Research Network of Historical Demography (FWO Flanders, http://www.historicaldemography.be) and the International Institute of Social History Amsterdam (IISH, http://socialhistory.org/). Manuscripts are reviewed by the editors, members of the editorial and scientific boards, and by external reviewers. All journal content is freely available on the internet at https://openjournals.nl/index.php/hlcs.

\section{Co-Editors-In-Chief:}

Paul Puschmann (Radboud University) \& Luciana Quaranta (Lund University)

hislives@kuleuven.be

The European Science Foundation (ESF) provides a platform for its Member Organisations to advance science and explore new directions for research at the European level. Established in 1974 as an independent non-governmental organisation, the ESF currently serves 78 Member Organisations across 30 countries. EHPS-Net is an ESF Research Networking Programme.

The European Historical Population Samples Network (EHPS-net) brings together scholars to create a common format for databases containing non-aggregated information on persons, families and households. The aim is to form an integrated and joint interface between many European and non-European databases to stimulate comparative research on the micro-level.

Visit: http://www.ehps-net.eu.
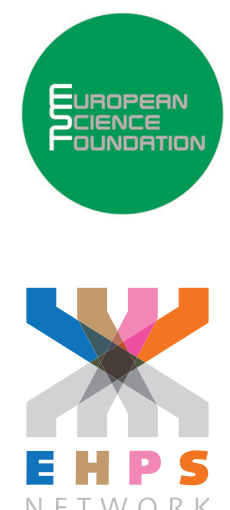


\title{
Grammar of Difference. General Education in the Netherlands and Java, 1800-1940
}

\author{
Elise van Nederveen Meerkerk \\ Utrecht University
}

\begin{abstract}
This contribution compares developments in school enrolment and public investments in primary education in the Netherlands and its most important colony in the 19th century: the Netherlands East Indies, more specifically the island of Java. Despite being part of the same Empire, conditions in both regions were very different, with the metropole having already quite high enrolment rates from the beginning of the period studied (the early 19th century) compared to very low school attendance in the colony. For long, the colonial government left indigenous education in Java to religious and private initiatives, whereas primary schooling in the Netherlands was increasingly financed and regulated. Rising interest for public schooling in the colony, including some government investment in the first decades of the 20th century did lead to some changes, but these were insufficient to prevent Dutch and Javanese children from experiencing a fundamentally different educational upbringing.
\end{abstract}

Keywords: Primary education, Children, The Netherlands, Java, Colonialism

e-ISSN: $\quad$ 2352-6343

DOI article: $\quad$ https://doi.org/10.51964/hlcs9579

The article can be downloaded from here.

(C) 2021, van Nederveen Meerkerk

This open-access work is licensed under a Creative Commons Attribution 4.0 International License, which permits use, reproduction \& distribution in any medium for non-commercial purposes, provided the original author(s) and source are given credit. See http://creativecommons.org/licenses/. 
Retirement inevitably leads to reflection. It also brings back memories of old loves, which were perhaps once lost, but never completely forgotten. After a career of having researched demographic big data, publishing widely on causes of death, marriage patterns, singles in the city, and the like, I want to take Kees back to one of his first loves: education. In 1996, he finished his, impressively lengthy, dissertation on the development of Dutch secondary education, particularly 'gymnasia' (grammar schools) and their students. Although Kees' academic path soon took different turns, he has probably never forgotten about education, especially since he became a teacher himself, to young researchers at the IISH, students at Erasmus University Rotterdam, and at numerous international summer schools. So, his retirement is an excellent opportunity to revert to this topic. I will do so comparing developments in primary education in the Netherlands and its most important colony in the 19th century: the Netherlands East Indies (present-day Indonesia), more specifically the island of Java. ${ }^{1}$ The results of this study show that the conditions in metropole and colony were very different from the outset, and that despite some colonial investments in education in the first decades of the 20th century, opportunities for Dutch and Indonesian children played out markedly differently.

\section{PRIMARY SCHOOLING IN THE NETHERLANDS}

The first national education laws in the Netherlands stemmed from the Napoleonic period (1801, 1803, 1806). The 1806 legislation, which remained in force until 1858 , stipulated rules for primary education in statefinanced schools. The national government prescribed the content of the curriculum: mainly reading, writing, Dutch language, and basic arithmetic, as well as criteria for the qualifications of teachers. Importantly, the law also explicitly postulated that state schools would not provide education based on religious principles. Non-state-funded 'special schools' (bijzondere scholen) could be established, but permission was only given by the authorities under strict conditions. This school system was inspired by the French revolutionary ideal of laïcité (secularism), but also matched well with the liberal course in Dutch politics in the first half of the 19th century.

Although compulsory education was only introduced in 1901, and state schools charged fees, the percentage of Dutch children enrolled in primary education rose steadily over the 19th century (see Figure 1). ${ }^{2}$ These figures correspond with research at the local level that suggests the effect of legislation in 1901 prescribing compulsory education was in fact relatively small, and that the law merely confirmed an existing situation. The law obliged every child under thirteen to have had six years of primary education. In 1921, this was raised to seven years, which effectively meant the continuation of schooling until the age of fourteen. For most Dutch children, education ceased after this age. The share of children receiving secondary education was negligible until the late 1920s, which is consistent with my observation that juvenile labour - that is, work by children over twelve years of age (and after 1919 over fourteen years) — was still very much prevalent until the Second World War (van Nederveen Meerkerk, 2019, p. 233).

Despite these favourable developments in Dutch general education from the early 19th century onwards, several confessional groups, including Catholics, orthodox Protestants, and Jews, were highly dissatisfied with the state-school system. They criticised it for its lack of freedom to provide proper religious, faith-based education. A fierce political 'school struggle' (schoolstrijd) emerged, with slow but steady landmarks for the confessionalists. The 1848 Constitution, for instance, in principle prescribed freedom of education, albeit under government supervision. However, an 1857 amendment to the Education Act stipulated that only secular schools were entitled to state subsidies. This distinction between state-funded and special, non-state funded, schools would remain a thorn in the side of the confessionalists. Another step forward for them was the 1889 School Act, which permitted subsidies for special schools under certain conditions. The struggle ended definitively only in 1917, when the confessionalists agreed a trade-off between full (financial) equality for public and religious schooling and universal (male) suffrage.

$1 \quad$ The following is based on section 6.4 of my recent monograph (van Nederveen Meerkerk (2019), pp. 239-246).

2 The paper accompanying the latest version of the Barro and Lee dataset (2016) is Lee and Lee (2016). 
Figure $1 \quad$ Enrolment rates (primary education) in \% of children aged 6-14, the Netherlands and the Netherlands Indies, 1820-1940

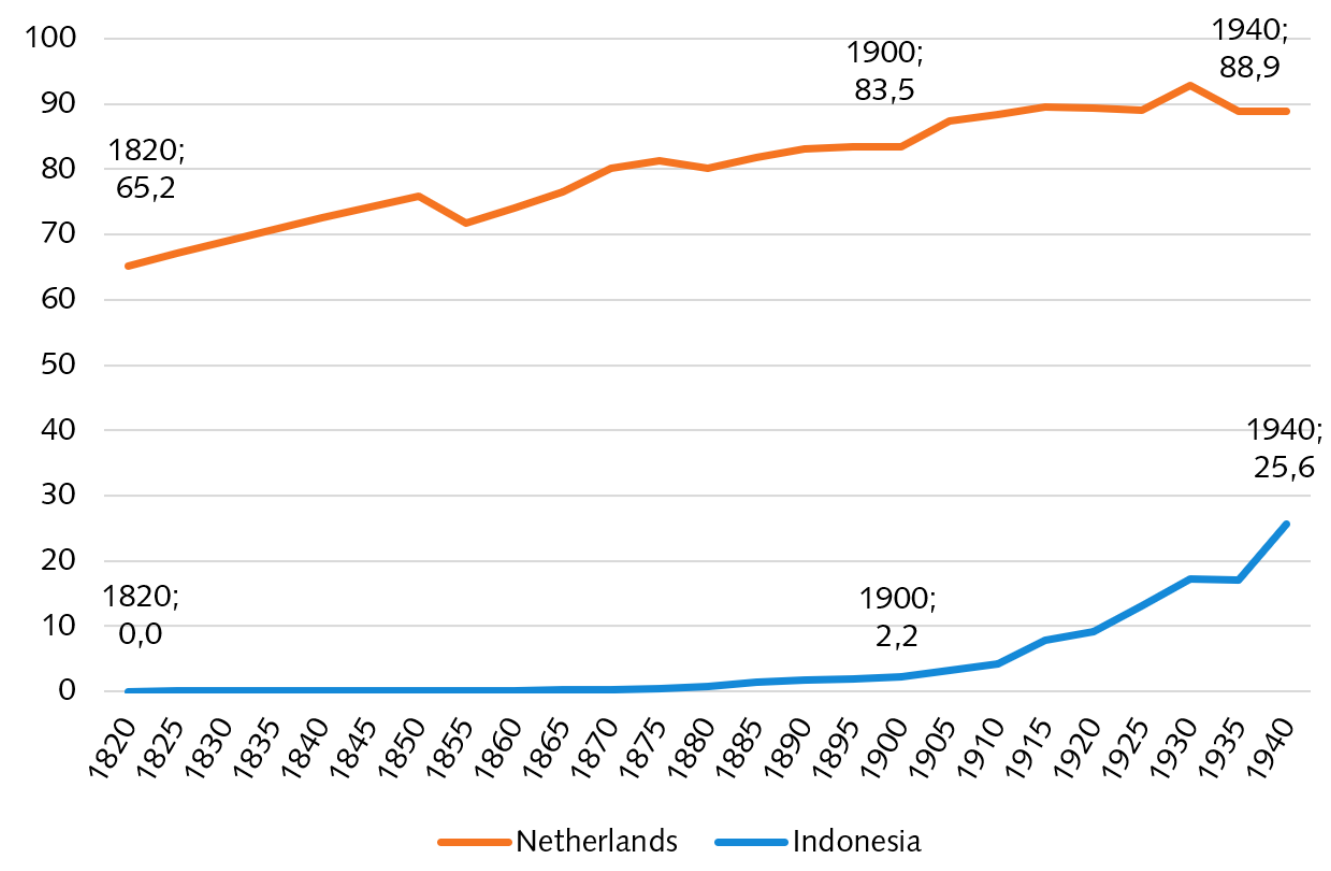

Source: Barro and Lee Dataset, version 2016.

\section{DEVELOPMENTS IN JAVA}

In its colonies, the Dutch colonial government paid hardly any attention to educating the indigenous population until circa 1860, which is evident from the enrolment rates in Figure 1. In 1827, there were only three publicly funded schools for indigenous Javanese children, and it was not until 1845 that colonial govenment, began to take this matter seriously. In 1859 the first law on the establishment of state indigenous education on Java was passed. However, by 1870 there were still only fifty-eight schools for indigenous pupils, with around 6,000 students out of a total of around thirteen million young Javanese. Not only were there few schools and teachers, their quality was deplorable in terms of knowledge, didactic skills, and material provisions such as proper school books.

In 1893, the colonial government passed an ordinance to stimulate indigenous schooling, introducing firstand second-class schools. The first-class schools provided five years of schooling for children of well-to-do indigenous people and village heads, the second-class schools offered three-year education to all other indigenous children. Second-class schools only taught basic reading and writing skills in the local language and some arithmetic. Interestingly, even elite children were not taught Dutch in the first-class schools, only reading and writing in their native language as well as arithmetic and subjects such as geography and Javanese history. Despite this ordinance, there were still only forty-three first-class schools in 1903, and a mere 245 second-class schools. In that same year, there were 326 private schools for indigenous children, among which mission schools. The number of schools was inadequate to meet demand: there was great pressure on the schools, as the number of students, and especially girls, had risen tremendously: from a little over 50,000 in 1892 to almost 86,000 ten years later. Given the huge and relatively youthful population of the colony, such figures were nevertheless negligible (van Nederveen Meerkerk, 2019, p. 242).

Partly under the influence of the 'Ethical Policy' (1901), which intended to further the wellbeing of the indigenous population of the Netherlands East Indies, things slowly but surely improved. In 1920 there were 4,710 'village schools' (desa schools, previously second-class schools) and 1,562 'normal' indigenous schools (previously first-class schools), with a total of almost 500,000 pupils. Over 22,500 Indonesian children went to one of the European schools. Enrolment rates among primary school children started to rise from a little over $2 \%$ of all children up to the age of twelve in 1900 to more than $9 \%$ in 1920 , and almost $26 \%$ on the eve of the Second World War. Nevertheless, these figures were still extremely low compared with the corresponding percentages for the Netherlands (see Figure 1). 


\section{DIFFERING INVESTMENTS AND IDEOLOGIES}

Clearly, this difference cannot be explained solely by legislation - after all, in the Netherlands general schooling had only become mandatory in 1901. Instead, the differences in investments in schooling appear to have been crucial. Although state expenditure on primary schooling rose quickly both in the Netherlands and the Netherlands East Indies in the late colonial period, per capita spending nevertheless differed significantly. Until the 1920s, the Dutch government spent around fourteen times more on primary education per head of the population in the Netherlands than in the Netherlands Indies (dataset on investments in schooling pertaining to Frankema, 2013). Despite the intentions of the Ethical Policy, the government only invested 300,000 guilders in indigenous schools, while it spent more than twice as much (700,000 guilders) on schools for the children of the circa 25,000 Europeans living in Java.

The lack of proper state schooling led to native as well as European private initiatives. Traditionally, there had been the religious schools (madrasah) that taught religious philosophy, the Koran, and some Arabic. The colonial government was ambivalent about this type of education, which many Dutch observers looked down upon, as it would 'haze and confuse the mental capabilities, instead of developing them' (Anonymous, 1870, p. 386). However, as the 1857 amendment to the Education Act also applied to the Netherlands Indies, the government was forbidden to finance religious schools. This excluded the possibility of countering Muslim education with co-financed state-private schools with a Christian signature. Confessional education in the colony was instead left to the missionaries, who were able to operate relatively autonomously until the early 20th century (Gouda, 1995, pp. 66-67). After 1900, several Dutch benefactors undertook private initiatives for non-religious schooling. Examples were the Kartini and Van Deventer schools, established in 1916 and 1917 respectively, for the provision of basic and advanced education to indigenous girls, with the objective of 'elevating (verheffen) the Javanese woman'. However, as a contemporary Javanese observer noted, the creation of Van Deventer schools meant that 'private foundations were fulfilling a task that should really be carried out by the government' (quoted in Gouda, 1995, p. 97).

Although the state indigenous schooling system was in principle open to both boys and girls, in practice, it primarily provided boys with the education necessary to enable them to maintain a family, or - for the higher classes - to prepare them for a career within the colonial administration. Moreover, many indigenous parents objected to their daughters being in the same classroom as boys. These obstructions are reflected in reported school enrolments rates for the period 1909-1922, which indicate that girls constituted only about $8 \%$ of the total number of pupils (Lelyveld, 1992, pp. 83 and 152). Likewise, the scarce data available on literacy rates also reveal low family investment in the education of girls: according to the 1930 census only $2.2 \%$ of indigenous women could read and write, while $10.8 \%$ of indigenous men were registered as literate. Among Dutch officials and citizens, this was not perceived as a problem, and it was believed that educating a small number of priyayi women would suffice to further disseminate knowledge and values to ordinary women (desa women or volksvrouwen). The same philosophy was pursued at the missionary schools in the archipelago. Such colonial perceptions, however, display a great deal of cultural insensitivity. Javanese elite women generally did not perform domestic tasks themselves, and the social distance between various indigenous social groups was large. Nevertheless, letters from the 1930s written by young female graduates to Mrs van Deventer-Maas, who, with her late husband, had founded the Van Deventer schools, reveal that some of the educated middle- and upper-class girls had internalized the desire to 'enter into the world to try to teach [their] knowledge to the Javanese people' (quoted in van Nederveen Meerkerk, 2019, p. 246). Some of these girls had very ambitious wishes, such as Willy Hamzah Amoendai, from Borneo, who hoped to establish a school in her home village.

\section{CONCLUSION}

All in all, this brief comparison of the development of, and state investment in, primary schooling in the Netherlands and the Netherlands Indies leads to some interesting observations. It seems that the Dutch authorities displayed an ambivalent attitude towards educating the common indigenous people. On the one hand, the Javanese population ought to be 'uplifted', preferably by non-religious general education, but this should certainly not cost too much. In the Netherlands, enrolment rates in primary education were already quite high at the start of the 19th century — and had gradually risen since - to around $85 \%$ when it was finally made compulsory by law in 1901. Since 1917, even special schools with a confessional signature received public funding in the Netherlands. Although enrolment rates as well as investments in 
Java started to rise after the introduction of the Ethical Policy, around three-quarters of indigenous children had never received primary schooling at the end of the colonial period, and literacy rates remained low, especially among girls. Accordingly, even in the 1930s, per capita public spending on general education in the Netherlands Indies was a fraction of what it was in the Netherlands. The accompanying ideology very much related to norms on child labour. By the early 20th century, labour by children below the age of fourteen had become considered undesirable in the mother country, which was reflected in high primary, but relatively stagnant secondary schooling enrolment rates. Conversely, the idea that indigenous children in Java should be in school instead of working never gained widespread currency. This was truly a 'grammar of difference'.

\section{REFERENCES}

Anonymous. (1870). Volks-onderwijs op Java. De Economist, 19(1), 384-387.

Barro, R., \& Lee, J. W. (2016). Data set educational attainment, version 2016 [Data set]. Pertaining to Lee, J. W., \& Lee, H. (2016). Human capital in the long run. Journal of Development Economics, 122, 147-169. doi: 10.1016/j.jdeveco.2016.05.006

Frankema, E. H. P. (2013). Database investment in education [Database]. Pertaining to Frankema, E. H. P. (2013). Why was the Dutch legacy so poor? Educational development in the Netherlands Indies, 1871-1942. Masyarakat Indonesia, 39(2), 307-326.

Gouda, F. (1995). Dutch culture overseas: Colonial practice in the Netherlands Indies, 1900-1942. Amsterdam: Amsterdam University Press.

Lelyveld, J. E. A. M. (1992). “... Waarlijk geen overdaad, doch een dringende eisch ...". Koloniaal onderwijs en onderwijsbeleid in Nederlands-Indië 1893-1942 [Unpublished doctoral dissertation]. Utrecht University.

van Nederveen Meerkerk, E. (2019). Women, work and colonialism in the Netherlands and Java. Comparisons, contrasts, connections, 1830-1940. London, etc.: Palgrave Macmillan. 